\title{
Cincinnati 1989
}

\author{
By Mary Ellen Rutledge Elsbernd
}

Director of Libraries

Northern Kentucky University

\section{ACRL's sixth national conference, April 5-9, 1989, will be held in the Queen City.}

\begin{abstract}
C by seven hills. Home port of the Delta Queen. Oktoberfest. Fountain Square. Airborne Skywalks. White Bengal Tigers. Riverfest's Fireworks Extravaganza. A blend of historic old-world charm and industrial high tech, of the formal and casual, of the conservative and outrageous. The place to be in April when baseball's opening day welcomes spring. The city that gave birth to professional baseball and celebrities such as Steven Spielberg, Pete Rose, Doris Day, Andy Williams, Roy Rogers, Tyrone Power, Jim Dine and the Isley Brothers.

Oh yes, Cincinnatians and ACRL librarians definitely share a great interest-throwing grand birthday parties! On December 31, 1987, some 50,000 local revelers converged upon Fountain Square and its environs for a gala event which kicked off the city's year-long celebration of its 200 th birthday. What a perfect place for ACRL to celebrate its 100th birthday! Make your plans now to attend "Building on the First Century," ACRL's sixth national conference, in Cincinnati, Ohio. Now back to highlights of the city where you must be during April 5-9, 1989.
\end{abstract}

\section{Historical footnotes}

Since there are scores of books which beautifully detail Cincinnati's heritage, let's take a quick pop history tour of Cincinnati's past. It all began in 1788 when a group of sturdy pioneers ran out of steam on the Ohio River and selected Yeatman's
Cove as their site of debarkation. This geographic location, a large natural basin on the Ohio downstream from Pittsburgh and a connector to the Mississippi, made brisk steamboat river trade natural. The fertile river bed also encouraged a thriving agriculture most notably in the form of hog farming, and Cincinnati, a.k.a. Porkopolis (a name the natives are still trying to forget), became the leading slaughterhouse and pork packing center for the country.

In a short time, Cincinnati's industry expanded in other forms to include iron and metalworking foundries which produced steamboat engines, teakettles, and spittoons, the manufacture of fine furniture for the South and Midwest, and a major production center for ready-to-wear clothing. Little wonder that this bustling city was dubbed "Queen City of the West" by Henry Wadsworth Longfellow and others before him. By the 1850s the Queen City was the fifth largest city in the U.S. and had assumed a distinctive Bavarian flavor due to the influx of German immigrants who had settled in a section that is still known today as Over the Rhine. Of primary value to these folks was a good education, religious faith, and an unfailing work ethic. They left a legacy which may be witnessed in the beautiful churches and cathedrals, educational institutions, and printing and machine tool industries. Lest one think they were "all work and no play," it is important to mention their lighter nature, which produced breweries, beer gardens, and the Sangerfest, Cincinnati's first German music 
festival. To this day, German influence can be seen in the city's traditional values, food, music, and language. When a visitor hears a native say, "Please?" (from bitte), it actually means "Excuse me, I didn't understand," not, "Yes, please."

During the latter part of the 19th century, the city's growth fizzled due to major competition for steamboat transportation, the railroad, and Chicago assumed the leadership role of the West. Despite the difficulties that two world wars, the Great Depression, and the Great Flood of 1939 posed for the Queen City, Cincinnati fathers forged an industrial and technological empire which is the key to contemporary Cincinnati's vitality.

\section{Cincinnati today}

Cincinnati. The Blue Chip City's metropolitan area ranks 27 th in the U.S. with a population of $1,401,491$ according to the 1980 census. Yep, whether you realize it or not, a piece of Cincinnati may touch your life on a daily basis. Let's talk soaps and cleansers galore, Ewoks, Joyce shoes, cosmetics, beer, Totes, playing cards, robotics, Carebears, cake mixes, wine, diapers, potato chips, jet engines.... The list is mind-boggling. Fortune 500 companies (Proctor and Gamble, Eagle-Picher, Cincinnati Milacron, Carlisle, Palm Beach, Kroger, Federated Department Stores, U.S. Shoe, Western-Southern Life Insurance, American Financial and Ohio Casualty) reside here and contribute to the city's quality of life by supporting its culture, arts, and technology with generous donations. Planned by 500 companies, organizations and individuals, the $\$ 5.5$-million Blue Chip City campaign is an aggressive development project targeted at enhancing existing business and attracting new companies. What a success story! Originally planned for a five-year period, the Blue Chip City campaign developers have reached their goal in three years and contribute this achievement to Cincinnati's central location, diverse economy, and moderate cost of living.

\section{Gadding about, day or night}

If traveling by air to the conference, don't be surprised when your pilot says, "Welcome to Kentucky"! The Greater Cincinnati Airport is definitely in the Bluegrass state, just twelve miles from downtown Cincinnati. Separated by the Ohio River (the Mason-Dixon line), Greater Cincinnati includes several counties in Northern Kentucky and Ohio and extends west into Indiana as well. Airport shuttles run to the downtown business area every twenty minutes and will take you to many of the major hotels. Shop until you drop via the twomile skywalk system which will connect you with the Convention Center, hotels, and major department stores (even a Saks Fifth Avenue!), restaurants, bookstores, libraries, art and music. Or if you prefer to travel in style, hop on a horse-drawn carriage to view the downtown sights. The Down- towner, part of the Queen City Metro bus service, travels the popular downtown route for only ten cents. If you're interested in more exotic gadding, there are always the hot air balloon trips that truly give you a bird's-eye view of greater Cincinnati!

\section{Queen City delights}

Interested in highbrow culture? Cincinnati boasts some of the best that the fine arts have to offer. Your options include the Cincinnati Symphony, the Cincinnati Pops Orchestra, the Cincinnati Opera (second oldest company in the U.S.), the Cincinnati Ballet (ranked in the nation's top ten), and the Playhouse in the Park. Museums tickle your fancy? Put on your sensible shoes and stroll through the Cincinnati Art Museum, the Taft Museum, the Contemporary Arts Center, Cincinnati Museum of Natural History and Planetarium, Cincinnati Fire Museum.... Ahh, the list goes on.

Animal lovers, the pièce de résistance is the Cincinnati Zoo. Touted by Newsweek as the world's sexiest zoo, the zoo is well-known for its success in breeding white Bengal tigers and gorillas. For flora and fauna enthusiasts, the parks, preserves, gardens, and arboretums are dressed in spring's finest in April. A paradise under glass, the Krohn Conservatory is a tropical miscellany of palms, citrus trees, orchids and papyrus and, yes, even a waterfall you can hide behind. Every spring, the Conservatory treats the city to a special exhibit of tulips, daffodils and crocus, and a spectacular Easter Lily show. A few miles outside of town lies the Cincinnati Nature Center, where you can breathe the glorious fresh air while bird-watching, admiring wildflowers and daffodils or hiking through lush vegetation. Back to the zoo-not only does it bring you the wild kingdom, it's a haven for botanists, with over 1,000 species of unusual plants.

\section{Sports}

Cincinnati. Major league sports. The Cincinnati Reds. Bengals. Horse racing at River Downs and Turfway Park. The championships of the Ladies Professional Golf Association (LPGA) and the Association of Tennis Professionals (ATP). College basketball and football. Great balls of fire, this town is sportswild! Pete Rose and Marge Schott offer you an opportunity of a lifetime to attend baseball's opening day game along with thousands of diehard fans during the first week of April. Strike up the bands! Preceding the game is the Findlay Market Opening Day Parade, which begins before noon and winds its 1.5-mile course from Findlay Market past Fountain Square. This is a parade, with more than 125 bands, floats and color guards and cheering fans. At this moment the exact date for opening day has not been determined. But stay tuned to this column, for the local arrangements committee has a hotline into the Reds Office and will issue the how, when and where of obtaining tickets in a forthcoming issue of CઐRL News. 


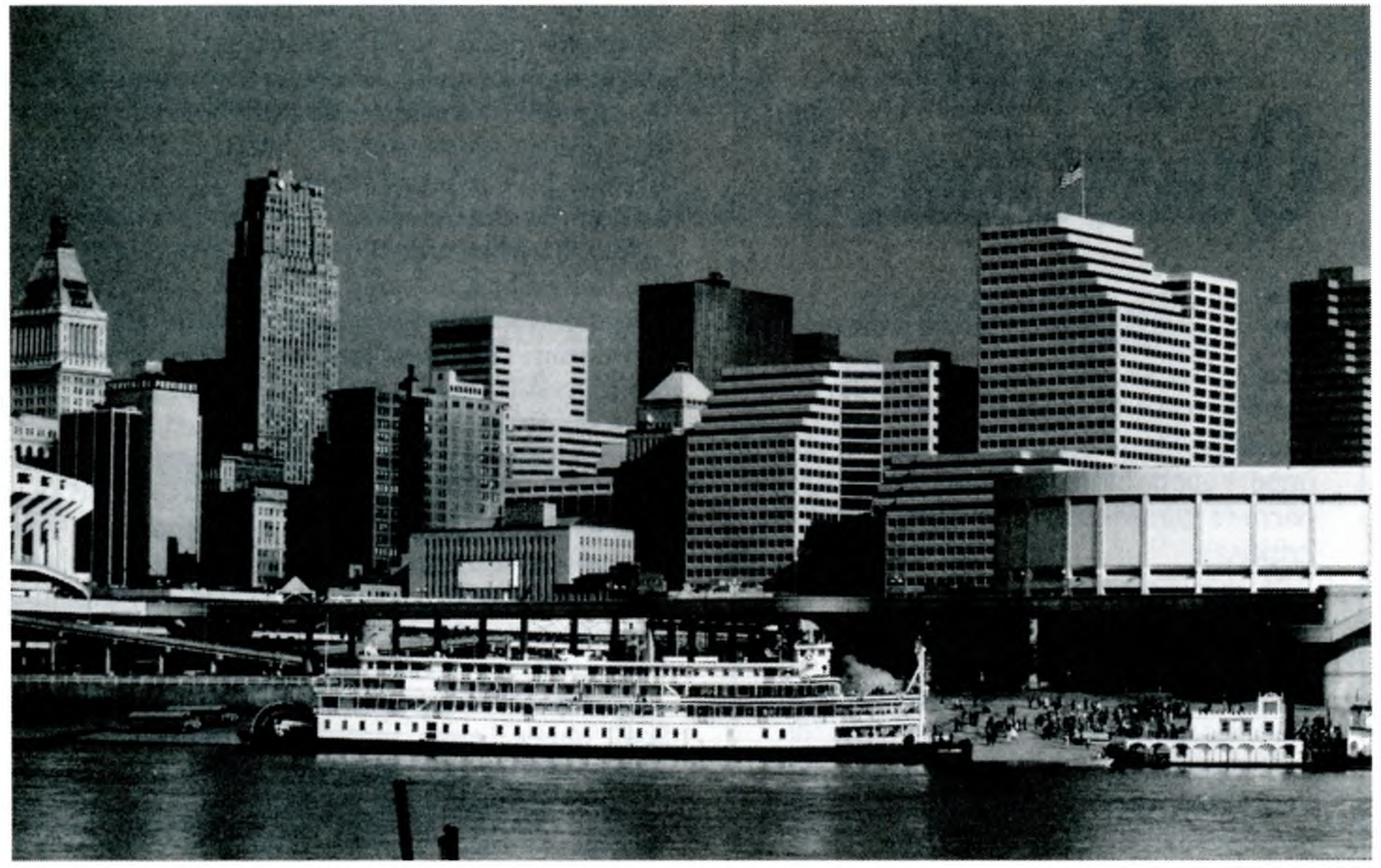

The Delta Queen and the Cincinnati skyline.

Credit: Bill Sutherland

\section{A taste of Cincinnati}

Let us not forget our daily bread, which Cincinnatians (and librarians) take very seriously and rightfully so. Whether it be simple tasty fare such as chili, metts, brats, a big fat yeasty pretzel, hot bagels or elegant dining in a Five-Star restaurant, the Queen City chefs will tantalize your tastebuds and have no mercy. If you prefer to revolve, float, or remain stationary on terra firma while eating, it's all possible in this burg which has many more Mobile Guide stars than others its size. Don't leave town without sampling our special recipe of chili which may be piled on spaghetti and loaded with cheese, onions, and beans and is ordered by natives in "ways": "Uh, I'd like a three-way, or on second thought, a four-way. No, make it a five-way and bring out the hot sauce." Sweet tooth fans, beat a path to Graeter's Ice Cream parlor and savor a dish of chocolate, chocolate chip ice cream with chips the size of the Hope diamond and calories, hmmm hmmm.

Restaurants. How about rooms with a view (The Celestial, Delmonico's, The Sovereign), rooms afloat (Crockett's, Mike Fink, Barleycorn's, On the Waterfront), revolving rooms (Top of the Crown, The Riverview Room) or places that specialize in seafood, Chinese, Japanese, Italian and German, or Indian cuisine. For a taste of old Bavaria, try Forest View Gardens where some of CCM's (Cincinnati Conservatory of Music) finest students perform and take your order. Just want all-American fare, the steak and ribs route? Try the Barn Rib Pit and enjoy a quintessential 1950s atmosphere. Bob Hope's favorite rib spot is the Montgomery Inn, and when he isn't in town, the ribs are airmailed to him! Some swear that the best steaks in town are grilled at the Precinct, which, if it means anything to you, the San Francisco Giants selected over restaurants in their own hometown for their team dinner celebration!

If you are bringing big bucks with you, the French prima donnas (the Maisonette, Pigalls, and the Gourmet Room) have been given enough stars by Mobile Guide to start their own galaxy. Whatever you yearn for can be found here. Take a tip from the locals-get lunch to go from a downtown deli and picnic on Fountain Square where something is always happening. For luncheons with unique atmosphere, try Arnold's Bar and Grill, established in 1861 and claimed to be the oldest in the city, or the Rookwood Pottery, where you can actually dine inside of a kiln that once created that famous pottery. The dinner plate has barely been scraped, so consult our local arrangements committee's guide to their favorite restaurants at the hospitality booth.

\section{Night crawlin'}

Warning for cocooners and couch potatoes who put on their jammies at 9 p.m.: "L.A. Law" and "MTV" are not substitutes for the nightlife in Cincinnati! Conference planners have left Thursday night open intentionally for you to make merry. If 


\section{Tough Questions?}

E very day, you're challenged by tough questions.

Where can I get a chronology of the Iran arms-Contra aid scandal? What legislative steps is Japan taking to remove import quotas and other non tariff trade barriers in response to U.S. and EEC criticism?

If your users want the answers to these and other public policy questions, it's time to search PAIS.

PAIS is the foremost indexing service covering national and international political, economic, and social issues. It's the unique, one-stop resource that gives you immediate access to a huge, eclectic range of material, including books, periodical articles, directories, government documents, statistics, and much more. And it's the only index of its kind that covers literature published around the world in English, French, German, Italian, Portuguese, and Spanish.

Where are your searches consistently productive, adding a valuable dimension to your research efforts? Where do you find answers to the toughest questions? Easy ... . PAIS!

PAIS is available in print, online, and now via CD-ROM. For information, call 800-841-1416. In New York or outside the continental U.S., call 212-736-6629.

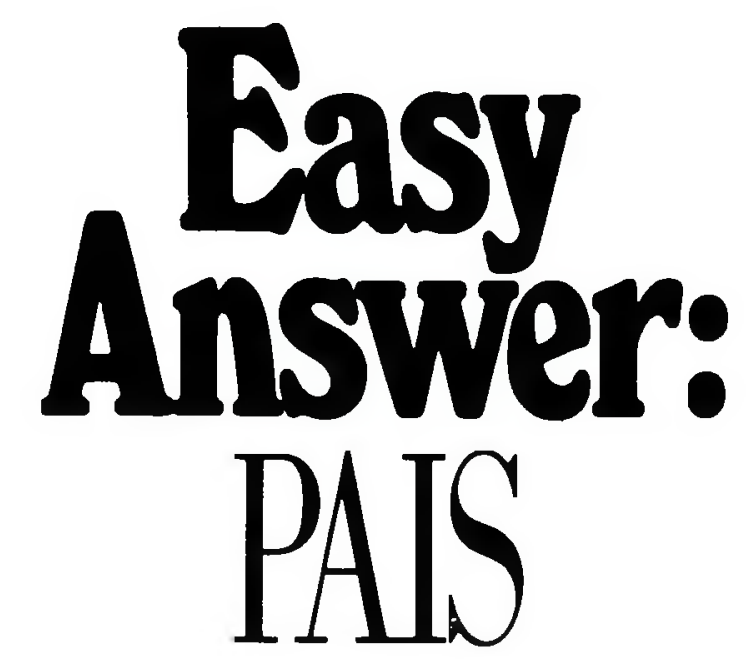

Public Affairs Information Service $11 \mathrm{~W} .40$ Street

New York, NY 10018-2693 it's laughter that you need, both Aunt Maudie's Comedy Revue and the Funny Bone have great reputations as comedy clubs. Check the local entertainment guide, the Downtowner, for amateur and open mike nights, and who knows, you may be the next Robin Williams. Bogart's books all kinds of big name entertainment, such as B.B. King, Stephen Stills, Count Basie, and the Blue Oyster Cult and is located in the University Village area.

Jazz/Rhythm and Blues/Soul! Whether it be a trio, soloist or a sixteen-piece band, the options for jazz aficionados are great. At one of the city's oldest clubs, some of the best jazz in town can be heard at the Blue Wisp Lounge and Jazz Club. "Jazz-Live from the Hyatt," at downtown's Hyatt Regency, is so popular that you're advised to arrive early ( 9 p.m.) for a seat. If your heart belongs to Dixie, pop over to Dee Felice's Cafe in Covington for a New Orleans style dinner and a first-rate Dixieland band. Arnold's Bar and Grill, Beagle's Lounge and C.J.'s Downunder are all part of the jazz connection.

Queen City of Soul. Would the Godfather of Soul, James Brown, record in a lightweight town? Home of the Isley Brothers, who brought us "Shout," Cincinnati is giving Motown a run for its money. "Love Overboard," "Jump Start My Love" and "Casanova" were all written by Cincinnati's Reggie and Vincent Calloway. Incidentally, they are the duo who are producing $\mathrm{R} \& \mathrm{~B}$ hits for Gladys Knight, Natalie Cole, Teddy Pendergrass and Lionel Ritchie. R \& B can be heard at Cory's Old Cincinnati Saloon, Mr. Kelly's, and Jello's. The best way to find out where R \& B is playing is to consult the Downtowner. If some of our local groups are jammin'-The Deele, Midnight Star, The Movies, Sharp or Visions-well, get down!

Folk/Rock/New Wave/Country \& Western. Any university town will have its share of folk music and good ole rock 'n roll. Around University Village, rock hangouts include Sudsy Malone's, Dollar Bill's Saloon, Hot Shotz, Kilgore's and the Plaza. If you're really into hard-core heavy metal with an atmosphere that is not for the faint of heart, the Jockey Club in Newport, Kentucky, will not disappoint you. The Blind Lemon in artsy Mount Adams still reigns as king for folk guitar music, and toetappin' bluegrass may be heard at Arnold's Bar and Grill. Country and Western, you bet, the hottest spot is in Wilder, Kentucky, called Bobby Mackey's. Bobby Mackey and the Freedom Express band will share their mike with you on Thursday night, and oh, let us know if you survive a ride on the mechanical bull.

That wraps up our sneak preview to the Queen City. In the months to come, there will be more articles in C\&RL News on things to do, places to go, and conference program updates. A wise person once said, "It's never too early to plan ahead for celebrating birthdays, especially if it's your 100th!” See you in Cincinnati in 1989 ! 